\title{
Free flap loss caused by heparin-induced thrombocytopenia and thrombosis (HITT): a case report and literature review
}

\author{
Trombocitopenia eparino-indotta e trombosi (HITT): una causa sottostimata \\ di fallimento di lembi liberi: case report e revisione della letteratura
}

\author{
E. SEGNA, A.R. BOLZONI, C. BASERGA, A. BAJ \\ Chirurgia Maxillo-facciale e Odontostomatologia, Fondazione IRCCS Cà Granda Ospedale Maggiore Policlinico, \\ Università degli Studi di Milano, Italy
}

\section{SUMMARY}

Heparin-induced thrombocytopenia and thrombosis (HITT) represents a dramatic condition that is difficult to diagnose because of nuanced clinical presentation. Therefore, in every case of microvascular thrombosis during heparin-therapy prompt suspicion about HITT is necessary to avoid flap necrosis. We present a case of HITT which, as the 8 other articles reviewed, clearly shows that HITT is difficult to diagnose and complex to manage. Microvascular reconstruction is the first choice in head and neck reconstruction; unfortunately, dramatic outcomes in free flap surgery due to unpredictable thrombotic events are still reported in the English literature. More knowledge is required about HITT and reaching a consensus about thrombotic prevention in microsurgery could be helpful. Furthermore, a careful anamnesis can help minimise unexpected situations.

KEY WORDS: Microsurgical free flap • Thrombosis • Blood coagulation disorder • Drug-related side effects and adverse reactions

\section{RIASSUNTO}

La trombocitopenia eparino-indotta con trombosi rappresenta una complicanza che può portare a esiti drammatici nella chirurgia ricostruttiva microvascolare, tanto più che il suo riconoscimento non è sempre semplice. In ogni caso di trombosi microvascolare, in corso di terapia eparinica, il sospetto di HITT deve subito insorgere, così da poter intercettare e trattare la catena di eventi che porterebbe alla necrosi del lembo ricostruttivo. Presentiamo un caso che dimostra quanto possa essere difficile la diagnosi di HITT, così come appare negli altri reports reperibili in letteratura internazionale. I lembi microvascolari sono il gold standard nella chirurgia ricostruttiva cervico-facciale: purtroppo però il successo della metodica può essere inficiato da eventi trombo-embolici imprevedibili. Crediamo che una maggior divulgazione e la formulazione di domande anamnestiche specifiche possano essere utili nel limitare le conseguenze devastanti della HITT.

PAROLE CHIAVE: Lembi liberi microchirurgici $\bullet$ Trombosi $\bullet$ Disordini della coagulazione $\bullet$ Reazioni avverse ai farmaci

Acta Otorhinolaryngol Ital 2016;36:527-533

\section{Introduction}

Microvascular tissue transfer is the first choice in the oral cavity reconstruction, especially in oncological resection ${ }^{1}$. The efficacy of this technique has progressively increased during years ${ }^{23}$ : improvements in optical technologies, surgeons' attitudes and confidence with head and neck microvascular reconstruction and all its anatomical variations ${ }^{4}$, in association with accurate patient selection have led to a global survival rate of $95-99 \%{ }^{5}$.

Despite this enormous success, there are still some unpredictable causes of failure: among thrombotic events, heparin-induced thrombocytopenia and thrombosis (HITT) represents a dramatic condition that is frequently misrecognised and consequently, very difficult to treat in a time- ly manner ${ }^{6-12}$. HITT has devastating outcomes and greater information and understanding are needed about the condition: until now, only 8 papers have been published in the English literature: herein we report our experience on HITT through presentation of a case report.

We conducted a research on PubMed focusing on 2 keywords "HITT/HIT + microvascular free flap reconstruction" and we found 6 publications and 1 systematic review reporting a total of 9 cases of HITT in microvascular surgery (Table I), confirming that HITT is not a widely documented condition in the medical literature. In 2008, Tremblay et al. ${ }^{6}$ described 2 cases of HITT in heparin naïve patients, both confirmed by positive anti-heparin antibody tests. They both suffered from venous congestion within hours following the intervention (respectively at 26 and 48 hours) af- 
Table I. Literature review.

\begin{tabular}{|c|c|c|c|c|c|c|c|c|c|}
\hline $\begin{array}{l}\text { Author, } \\
\text { year }\end{array}$ & $\begin{array}{l}\text { Number } \\
\text { of } \\
\text { patients }\end{array}$ & $\begin{array}{l}\text { Clinical } \\
\text { manifestation } \\
\text { (arterious, } \\
\text { venous) }\end{array}$ & Onset time & $\begin{array}{l}\text { Time } \\
\text { to hitt } \\
\text { diagnosis }\end{array}$ & $\begin{array}{l}\text { Pre-hitt } \\
\text { therapy }\end{array}$ & $\begin{array}{l}\text { Post-hitt } \\
\text { therapy }\end{array}$ & Hitt therapy & $\begin{array}{l}\text { Previous } \\
\text { herapin } \\
\text { exposure }\end{array}$ & $\begin{array}{l}\text { Confirmation } \\
\text { of Hitt by } \\
\text { antibody test }\end{array}$ \\
\hline $\begin{array}{l}\text { Tremblay, } \\
2008\end{array}$ & 2 & $\begin{array}{l}\text { Case 1: venous } \\
\text { congestion } \\
\text { Case 2: venous } \\
\text { congestion }\end{array}$ & $\begin{array}{l}\text { Case 1: } 26 \\
\text { hours } \\
\text { Case 2: } 48 \\
\text { hours }\end{array}$ & $\begin{array}{l}\text { Case 1: } 12 \\
\text { days } \\
\text { Case 2: } 11 \\
\text { days }\end{array}$ & $\begin{array}{l}\text { Case 1: } \\
\text { Heparin } 5000 \\
\text { U sc twice } \\
\text { daily } \\
\text { Case 2: } \\
\text { Heparin } 5000 \\
\text { U sc twice } \\
\text { daily, ASA } 80 \\
\text { mg daily }\end{array}$ & $\begin{array}{l}\text { Case 1: } \\
\text { heparinised } \\
\text { gauzes, } \\
\text { Leeches, } \\
\text { Heparin } \\
\text { perfusion } \\
\text { Case 2: } \\
\text { continuous } \\
\text { heparin infusion, } \\
\text { Heparin } 6000 \\
\text { U boluses, } \\
\text { Leeches }\end{array}$ & $\begin{array}{l}\text { Case 1: } \\
\text { Heparin } \\
\text { discontinued, } \\
\text { Argatroban } \\
\text { Case 2: } \\
\text { Heparin } \\
\text { discontinued, } \\
\text { Orgaran for } \\
17 \text { days }\end{array}$ & $\begin{array}{l}\text { Case 1: no } \\
\text { Case 2: } \\
\text { unknown }\end{array}$ & Case $1 \& 2$ : yes \\
\hline $\begin{array}{l}\text { Schleich, } \\
2008\end{array}$ & 1 & $\begin{array}{l}\text { Venous } \\
\text { thrombosis, } \\
\text { decreased } \\
\text { doppler sign }\end{array}$ & 6 hours & 6 hours & $\begin{array}{l}\text { Systemic } \\
\text { herapinisation }\end{array}$ & $\begin{array}{l}\text { IV derapi } \\
\text { perfusion }\end{array}$ & $\begin{array}{l}\text { Heparin } \\
\text { discontinued, } \\
\text { Argatroban } \\
\text { for } 5 \text { days, } \\
\text { long term } \\
\text { Warfarin for } 3 \\
\text { months }\end{array}$ & Unknown & Yes \\
\hline $\begin{array}{l}\text { Busch, } \\
2009\end{array}$ & 2 & $\begin{array}{l}\text { Case 1: } \\
\text { malperfusion } \\
\text { Case 2: arterial } \\
\text { thrombosis }\end{array}$ & $\begin{array}{l}\text { Case 1: } 12 \\
\text { hours } \\
\text { Case 2: } \\
\text { referred } \\
\text { from another } \\
\text { hospital }\end{array}$ & $\begin{array}{l}\text { Case 1: } \\
\text { unknown } \\
\text { Case 2: } \\
\text { unknown }\end{array}$ & $\begin{array}{l}\text { Case 1: } \\
\text { unknown } \\
\text { Case 2: } \\
\text { unknown }\end{array}$ & $\begin{array}{l}\text { Case 1: } \\
\text { unknown } \\
\text { Case 2: } \\
\text { unknown }\end{array}$ & $\begin{array}{l}\text { Case 1: } \\
\text { Heparin } \\
\text { discontinued, } \\
\text { Lepirudin } \\
\text { Case 2: } \\
\text { Heparin } \\
\text { discontinued, } \\
\text { Lepirudin }\end{array}$ & $\begin{array}{l}\text { Case 1: } \\
\text { unknown } \\
\text { Case 2: } \\
\text { yes }\end{array}$ & Case $1 \& 2$ : yes \\
\hline $\begin{array}{l}\text { McCleave, } \\
2010\end{array}$ & 1 & $\begin{array}{l}\text { Venous } \\
\text { congestion and } \\
\text { thrombosis, } \\
\text { venous } \\
\text { and arterial } \\
\text { thrombosis }\end{array}$ & 5 days & 6 days & $\begin{array}{l}\text { LMWH preop, } \\
\text { Heparin } \\
5000 \mathrm{U}\end{array}$ & Heparin infusion & $\begin{array}{l}\text { Heparin } \\
\text { discontinued, } \\
\text { Lepirudin, } \\
\text { long term } \\
\text { Warfarin }\end{array}$ & No & $\begin{array}{l}\text { Antibody test } \\
\text { negative, } \\
\text { but platelet } \\
\text { aggregation } \\
\text { assay positive }\end{array}$ \\
\hline $\begin{array}{l}\text { Medina, } \\
2010\end{array}$ & 1, 2 flaps & $\begin{array}{l}\text { 1st flap: } \\
\text { venous } \\
\text { congestion, } \\
\text { necrotic tissue } \\
\text { 2nd flap: } \\
\text { venous } \\
\text { congestion }\end{array}$ & $\begin{array}{l}\text { st flap: } 4 \text { days } \\
\text { 2nd flap: } 1 \\
\text { day }\end{array}$ & 12 days & ASA, Lovenox & $\begin{array}{l}\text { Heparin } 5000 \mathrm{U} \\
\text { boluses }\end{array}$ & $\begin{array}{l}\text { Heparin } \\
\text { discontinued, } \\
\text { Leeches, } \\
\text { Argatroban, } \\
\text { long term } \\
\text { Coumadin }\end{array}$ & Unknown & $\begin{array}{l}\text { No. HITT } \\
\text { confirmed by } \\
\text { hypercoaguable } \\
\text { workup }\end{array}$ \\
\hline $\begin{array}{l}\text { Tessler, } \\
2013\end{array}$ & 1, 2 flaps & $\begin{array}{l}\text { 1st flap: } \\
\text { venous } \\
\text { congestion, } \\
\text { decreased } \\
\text { doppler sign } \\
\text { 2nd flap: } \\
\text { arterial } \\
\text { thrombosis }\end{array}$ & $\begin{array}{l}\text { Immediately } \\
\text { compromised, } \\
\text { 1st flap } \\
\text { failure: } 2 \text { days } \\
\text { 2nd flap } \\
\text { failure: } 6 \text { days }\end{array}$ & 6 days & $\begin{array}{l}\text { Heparin drips, } \\
\text { leeches }\end{array}$ & $\begin{array}{l}\text { tPA } 6 \text { mg } \\
\text { in a close } \\
\text { loop circuit, } \\
\text { Enoxaparin } 40 \\
\text { mg sc daily }\end{array}$ & $\begin{array}{l}\text { Heparin } \\
\text { discontinued, } \\
\text { fondaparinux, } \\
\text { long term } \\
\text { Warfarin }\end{array}$ & Unnown & Yes \\
\hline $\begin{array}{l}\text { Zaman, } \\
2014\end{array}$ & 1 & $\begin{array}{l}\text { Arterial } \\
\text { thrombosis }\end{array}$ & 6 hours & Unknown & Unknown & $\begin{array}{l}\text { Heparin } 5000 \text { U } \\
\text { iv, Heparin } 5000 \\
\text { U twice daily }\end{array}$ & $\begin{array}{l}\text { Heparin } \\
\text { discontinued, } \\
\text { Danaparoid } \\
\text { infusion }\end{array}$ & Unknown & Yes \\
\hline
\end{tabular}

ter having received unfractioned heparin (UFH). The first case was treated with leeches and anticoagulation therapy (argatroban) for about 1 month until he had a total free flap loss. In the second case, heparin was stopped promptly and danaparoid sodium was started, which worked adequately.
Schleich et al. ${ }^{7}$ reported a case of HITT in a patient treated with a latissimus dorsi flap with an unknown story of heparin exposure. Six hours after surgery a decreased arterial Doppler signal, platelet count drop and positive antibody test confirmed a suspicion of HITT. Heparin was inter- 
rupted and anticoagulation was switched to argatroban. Warfarin was mandatory as long term therapy.

In 2009, Busch et al. ${ }^{8}$ published 2 cases of HITT with a total flap loss with early onset, recurrent arterial thrombosis and no significant decrease in platelets. In the first case, HITT was diagnosed 12 hours post-operatively and was confirmed by positive antibody test in a patient with previous heparin exposure. Microvascular anastomoses were unsuccessfully revised 12 times. The second case reported was a flap failure due to HITT that occurred at an unknown period after surgery. HITT antibodies were positive and heparin was immediately stopped and changed into lepirudin; the defect was reconstructed with a second free flap 10 days after heparin suspension.

McCleave et al. ${ }^{9}$ published a paper in 2010 describing the case of a heparin naïve patient which had both an arterial and a venous congested flap 5 days after surgery with a negative antibody test and a positive platelet aggregation assay. He was unsuccessfully treated with exploration, heparin was interrupted and lepirudin was initiated. Warfarin was also mandatory as long-term therapy in this case.

In 2010 a paper by Medina et al. ${ }^{10}$ reported the failure of 2 free flaps due to HITT in the same patient with unknown prior heparin exposure. Four days after performing the $1^{\text {st }}$ flap, a second one was done. Venous congestion was noted immediately in the $2^{\text {nd }}$ flap, which was successfully treated with leeches and argatroban. HITT was diagnosed thanks to a hypercoagulability workup.

Tessler et al. ${ }^{11}$ in their review in 2013 analysed the literature by dividing papers in 3 groups: prior heparin exposure, heparin naive and prior heparin status not discussed. In each group, the number of patients, HITT flap characteristics, time until flap failure, treatment of HITT and confirmation of HITT by antibody test were analysed. They also reported a case of an ALT flap failure 2 days after surgery in a patient with a chronic right malleolus wound and no story of previous heparin exposure. Anastomosis were revised twice and a therapy with IPA in the operating theatre and leeches afterward was used, and starting on the $4^{\text {th }}$ day RFFF was performed and persisted with good perfusion for 4 days. Thrombosis manifested again: thrombolysis with tPA and attempt of re-anastomosis were done unsuccessfully; the final decision was positioning a vacuum assisted closure therapy. HITT was diagnosed afterwards using an ELISA test and heparin was immediately stopped in favour of fondaparinux. Despite anticoagulant therapy, a trans-tibial amputation was needed because of deep venous thrombosis (DVT).

Zaman et al. ${ }^{12}$ wrote a letter to the editor in 2014 to expose a case of a free gracilis flap partial failure 6 hours after surgery due to an arterial thrombosis, so the arterial anastomosis was revised. Post-operatively over the next few days the flap again showed signs of failure. At re-exploration, both the artery and vein were thrombosed and it was impossible to re-establish flow. The flap was removed, the wound debrided and a negative pressure dressing was applied. The platelet count was trending downward prior to the gracilis free flap. A diagnosis of HITT was considered and anti-heparin antibody assays were positive. Heparin was ceased and the patient was started on danaparoid infusion. The platelet count returned to normal limits within 3 days following cessation of heparin. Because of platelet count stability, his lower limb defect was reconstructed with a right latissimus dorsi free muscle flap. This second flap had an unremarkable post-operative course.

\section{Case report}

A 40-year-old non-smoking man, F.M., with no co-morbidities presented. He reported a fracture of the right knee, occurring 20 years ago; we after discovered that on this occasion he had had anti-thrombotic prophylaxis with sub-cutaneous heparin.

The patient came to our attention for squamous cell crcinoma (SSC) of the lateral border of the tongue (cT2N0), diagnosed in September 2015. We performed the usual pre-operative assessments (blood exam, ECG, chest radiograph, anaesthesiological evaluation) and no surgical contraindications were found. We performed partial glossectomy, selective neck dissection level I-III, and the defect was reconstructed with a left anterolateral thigh (ALT) flap. As per our routine, before cutting the descending branch of the deep circumflex artery, a heparin bolus was administered (2500 I.U.). The arterial and the two venous microanastomoses were performed on the superior thyroid artery and on the thyreolinguofacial trunk and on the superior thyroid vein, respectively. During the microsurgical time, the vessels were washed only with heparinised solution. Intra-operative angiography with indocyanine green was negative. The surgery was carried out unremarkably, and no surgical or anaesthesiological problems were seen. As per routine, we prescribed nadroparin 4000 I.U. daily. About 24 hours after surgery the flap appeared mildly congested, and application of medical leeches was initiated. We continued with hourly flap monitoring, but the clinical suspicion of mild-to moderate congestion persisted. On the morning of the 2nd post-operative day the flap colour had turned to blue, the temperature was decreased and the blood color, at the puncture, was quite dark: the patient was thus returned to the operating theatre. As expected, multiple venous thrombi were detected while the arterial flow was still valid. We attempted to remove the thrombi with direct administration of fibrinolytic drugs ( $6 \mathrm{mg}$ of tissue plasminogen activator [tPa]) and by mechanical thrombolysis with a Fogarty catheter. Both maneuvers were relatively ineffective: the artery was still working, but without venous drainage. The flap appeared to be irrecoverable, so we removed the ALT flap and reconstructed the tongue defect with a left radial 
forearm free flap (RFFF): the microvascular anastomoses were performed again on the superior thyroid artery and the internal jugular vein, in a termino-lateral fashion. Vessel patency was tested with indocyanine green. The RFFF showed a good perfusion for about 24 hours; unfortunately, impairment of the venous drainage was noted on post-operative day 3 . The patient was returned to the operating theatre again. At surgical exploration, we discovered the left internal jugular vein completely occluded by thrombi. We tried once again to remove the thrombi, but they continued to reform intraoperatively and it was not possible to re-establish venous flow. The flap appeared still alive and so we performed a second venous anastomosis on the superior thyroid vein (Fig. 1). At the end of this third surgery, the flap perfusion was good and continuous heparin infusion had been started to contrast thrombophilia. During these 72 hours, blood exam, coagulation test and platelet counts did not show significant alterations (Fig. 2), and the patient's general conditions were good. After about 24 hours of intravenous heparin (3000 I.U./day), haematomas formed in each surgical site (left thigh, left forearm, left neck): we evacuated the cervical and the antebrachial haematomas in the operating room. The flap perfusion continued well, the forearm skin was pink and no stasis was detected (Fig. 3). The situation worsened on the 5th post-operative day: the RFFF started

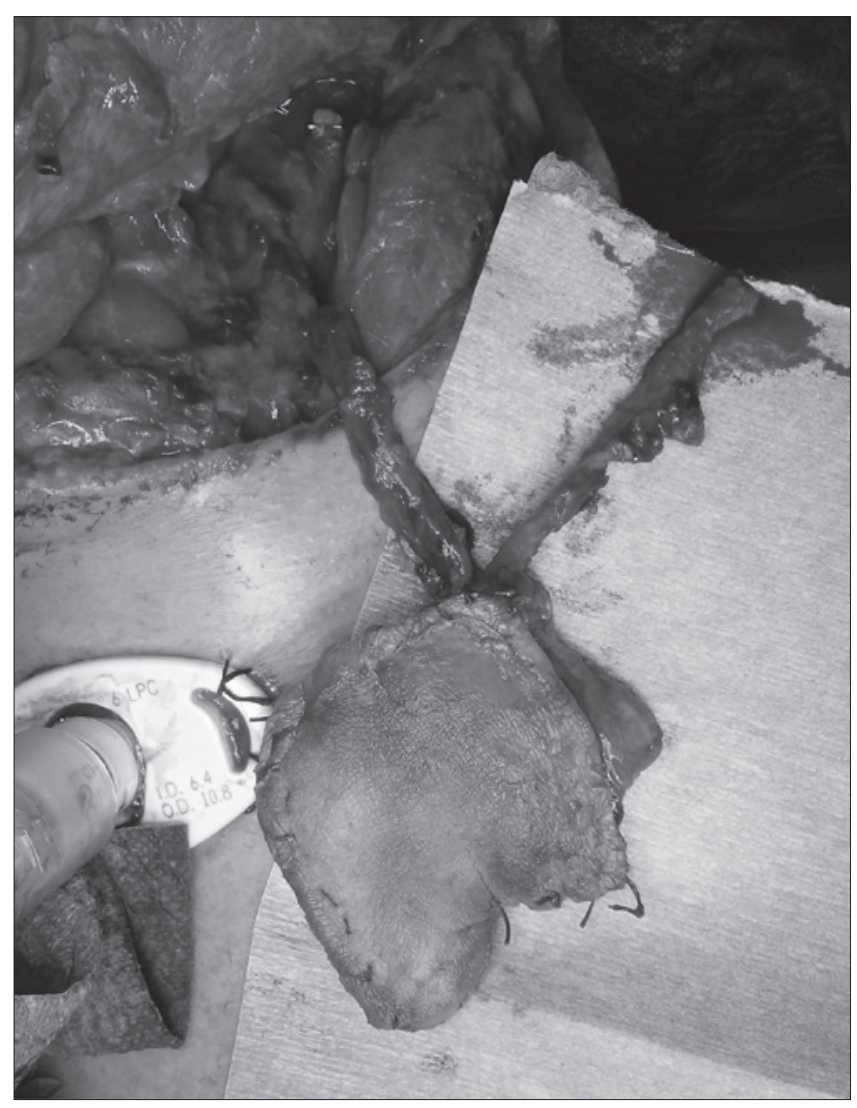

Fig. 1. Radial forearm free flap well perfused. to suffer, it became blue (Fig. 4) and, in addition to the local problem, systemic manifestations showed: venous accesses, both peripheral and central, did not work and the blood in drainage sack coagulated very quickly. We performed another surgery: the forearm flap appeared very congested, we tried once again to restore venous flow, but

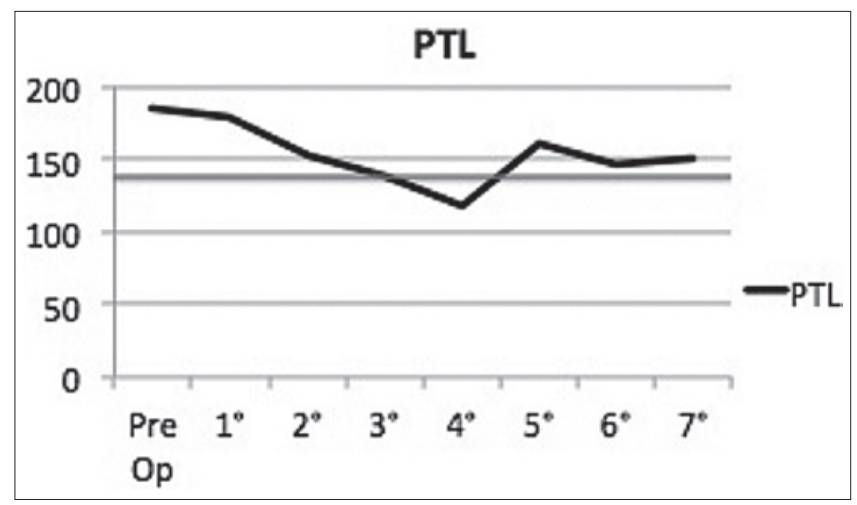

Fig. 2. Platelet profile during post-op days.

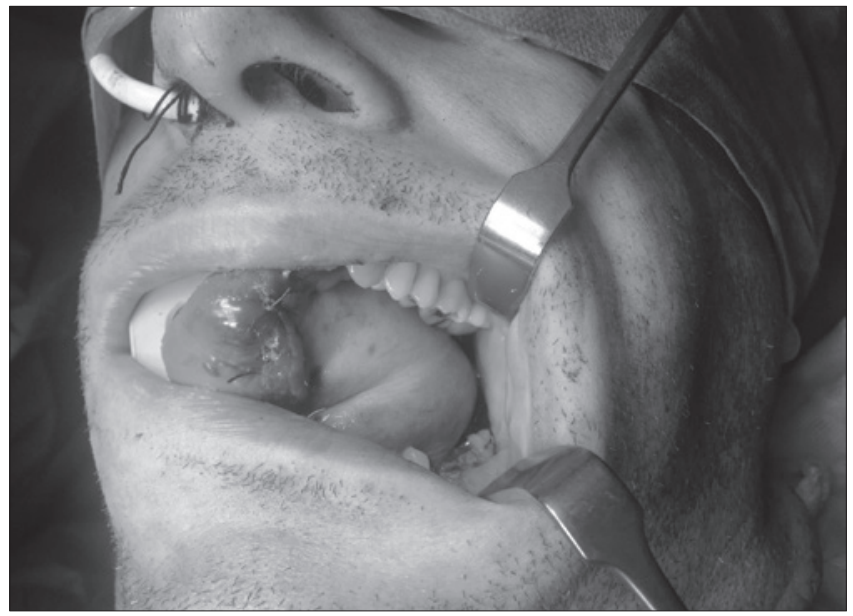

Fig. 3. Radial forearm free flap, after the second re-exploration.

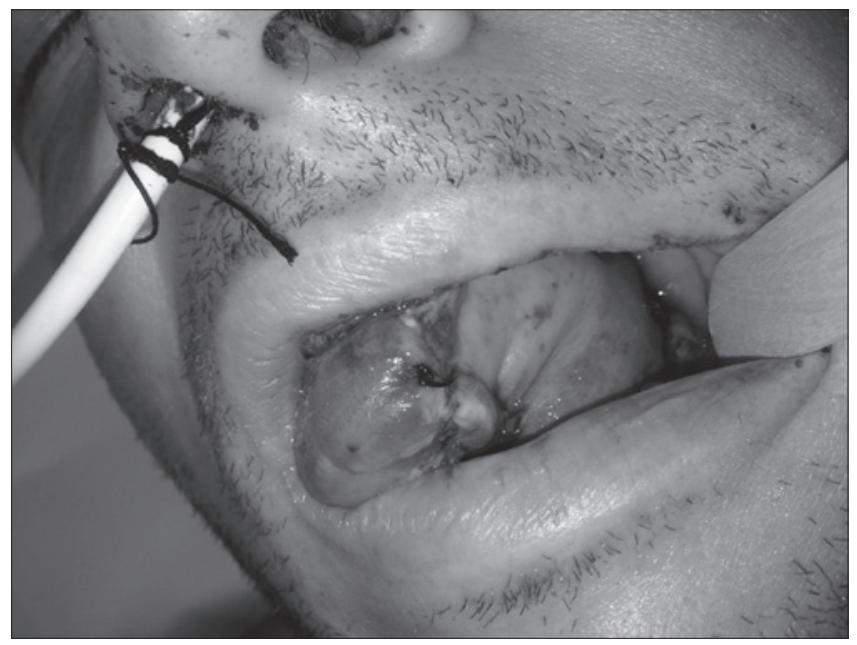

Fig. 4. Venous stasis of the radial forearm free flap. 
every attempt was unsuccessful. We finally decided to remove the flap and to change the reconstructive technique: the wound was closed with a facial artery myo-mucosal (FAMM) flap.

A haematologist was consulted and specific coagulation tests were performed: on the morning of the 6th postoperative day we received the results: heparin-PF4 antibodies resulted positive by enzyme-linked immunoassay (ELISA). The haematologist rendered a diagnosis of HITT. We promptly substituted low body weight heparin (LBWH) with fondaparinux, a synthetic heparin-like polysaccharide targeting only the coagulation factor Xa and without affinity for PF4, avoiding the formation of heparin/PF4 antibody complexes. In the following days, the platelet count, which had dropped at least at $120 \times 10^{9}$ at the apex of the manifestations on the 5 th day, increased to $483-529 \times 10^{9}$, further supporting a diagnosis of HITT. The patient's recovery continued without complications, and the fondaparinux dose was increased up to $7.5 \mathrm{mg} /$ day. He was discharged on the 21 th day after the first surgery; 3 weeks later the autonomization of the pedicled flap was accomplished without further complications.

\section{Discussion}

HITT is a syndrome caused by the presence of antibodies linked to complex platelet factor 4 (PF4), which are exposed after heparin linkage. Among all antibodies, IgG are those that provoke platelet activation and aggregation, leading to thrombocytopenia and, in $50 \%$ of cases, thrombotic events. A diagnosis of thrombocytopenia is made when the platelets count is less than $150,000 / \mathrm{mm}^{3}$ or when the decrease is more than $50 \%$; the thrombotic events usually involve veins, with a venous:arterious ratio of $4: 1^{13}$. HITT manifests in two different forms. Type 1 depends on the direct activation of platelet heparin-mediated and is asymptomatic: thrombocytopenia resolves spontaneously in 1-2 days, normally without thrombotic events, and no intervention is usually required ${ }^{14}$. HITT type 2 is platelet activation mediated by immuno-complex ${ }^{15}$ : it manifests later, usually in 4-10 days after heparin exposure and thrombotic events are co-existing, usually involving organs or tissues with pre-existing endothelial injury ${ }^{16}$; there is also a so-called "local-form" characterised by flap loss occurring very early in the post-operative course, with no drop in platelet counts ${ }^{8}$. The risk of developing HITT is correlated to the type of heparin: the major risk is with bovine heparin and with LBWH. The antibodies completely disappear in 100 days ${ }^{17}$. Rapid diagnosis of HITT is challenging: it manifests in unexpected ways, it's hard to recognise and unfortunately the consequences of diagnostic delay can be dramatic: flow impairment to the flap can result in flap loss, nullifying the efficacy of the surgery ${ }^{18}$. Typically heparin prophylaxis is administered to prevent venous flow impairment; when venous suffering is recognised, leech therapy is usually introduced, and can gradually resolve the situation. If leeches do not work, surgical revision is required: during surgery it is possible to directly see anastomosis, remove thrombi and locally administer fibrinolytic drugs, such as t-PA.

There is no general consensus about thrombosis prevention ${ }^{19}$, but heparin therapy still remains a cornerstone during postoperative microsurgery: the paradox is that the therapy is the cause of the thrombosis, and this explains the difficulty in diagnosing HITT. Laboratory tests typically show thrombocytopenia after clinical manifestations that could be referred to other causes; systemic manifestations of thrombosis do not manifest, sustaining the probability of a local problem. Furthermore, routine anamnesis does not investigate prior heparin therapy, and even if well investigated, prior assumption of heparin is not an essential diagnostic information because it could occur even in heparin naive patients ${ }^{9}$.

When the microsurgeon has to face venous drainage complications the first doubt is technical error ${ }^{20}$. In routine surgical activity, local problems are more easily believed to be the cause of venous congestion, more than a misdiagnosed systemic condition. All these aspects clarify the problems in HITT diagnosis: the time gap between the first clinical sign and diagnosis is usually enough to lead to irrecoverable damage (Table I). Hypercoagulability state, hereditary or acquired, is quite frequent in the general population and unrecognised coagulopathies represent a significant cause of flap failure $^{21}$. We also have to consider the typology of patient undergoing reconstruction in head and neck surgery: the patient is usual oncological, as in our case, and frequently is a heavy smoker: both these factors increase propensity to clot formation. Furthermore, microsurgery itself may concur to thrombosis: the handling of vessels, with micro-damage on the endothelium, and the long surgical time, with prolonged immobilisation, may play a role in thrombotic aetiology. Dramatic outcomes in free flap surgery due to unpredictable thrombotic events are reported in the literature: from the experience with unknown coagulopathic patients the importance of specific anamnesis can be recognised, investigating about thrombophilia, not only in the patient but also in the family ${ }^{22}$; differently, the patient at risk for HITT cannot be recognised previously: the search for antibodies cannot be routinely performed and is not useful because they disappear at about 100 days after the manifestations; perhaps the only useful anamnestic data is previous exposure to heparin but, as already mentioned, is not specific for HITT diagnosis. Diagnosis is assessed only with a laboratory test that should be requested as soon as possible in order to break the chain of events: a prompt suspicion of HITT may be helpful in reducing negative outcomes. Warkentin and Heddle suggested a 
Table II. 4T score.

\begin{tabular}{|c|c|c|c|}
\hline $4 T$ 's & 0 POINT & 1 POINT & 2 POINT \\
\hline Thrombocytopenia & $\begin{array}{l}<30 \% \text { platelet count fall or }<10 x \\
10^{9} / \mathrm{L} \text { platelet nadir }\end{array}$ & $\begin{array}{l}\text { A } 30-50 \% \text { decrease in platelet } \\
\text { count or platelet nadir } 10-20 \times 10 \% / \mathrm{L}\end{array}$ & $\begin{array}{l}>50 \% \text { fall in platelet count or nadir } \\
2-100 \times 10^{9} / L\end{array}$ \\
\hline Timing of platelet count fall & $\begin{array}{l}\text { Early drop ( }<4 \text { days) in platelet } \\
\text { count in never exposed }\end{array}$ & $\begin{array}{l}\text { Onset after } 10 \text { days, or some } \\
\text { platelet count data missing }\end{array}$ & $\begin{array}{l}\text { Clear onset between } 5-10 \text { days after } \\
\text { initiation of heparin, or platelet fall } \\
1 \text { day }\end{array}$ \\
\hline Thrombosis _ other sequela & None & Progressive or recurrent thrombosis & $\begin{array}{l}\text { New thrombosis (confirmed), skin } \\
\text { necrosis present, systemic reaction } \\
\text { to heparin bolus }\end{array}$ \\
\hline Other causes of thrombocytopenia & Definite & Possible & No alternative explanation \\
\hline
\end{tabular}

pre-lab test score ("4T score") ${ }^{23}$ : clinical data and lab exam determine the grade of risk for HITT (Table II): evidence of a low score demonstrates unlikely HITT $(<5 \%)$, an intermediate score (4-5) has a clinical profile of HITT, but alternative explanations may still be relevant, and finally a high score representing a likely case of HITT $(>80 \%)$. This clinical score has been evaluated by both prospective and retrospective studies and has been demonstrated to have a predictive negative value (PNV) of $100 \%{ }^{24}$. Whenever thrombotic complications occur HITT diagnosis should be considered, and this clinical test should be kept in mind as it allows addressing suspicions toward intrinsic alterations in coagulation.

\section{Conclusions}

In reconstructive microsurgery unexpected thrombosis is a very serious complication that, if untreated, can lead to flap necrosis. A prompt and correct diagnosis followed by appropriate therapy is mandatory. The microsurgeon usually suspects technical error or some other local problem; systemic alterations are considered as a possible cause of thrombosis secondarily, also because routine coagulation tests are considered sufficient to discriminate coagulopathic patients. Furthermore, the absence of a general consensus about post-operative anticoagulation therapy complicates the management of thrombotic manifestations. The case presented summarises very well as diagnosis of HITT is difficult: a healthy young patient, non-smoker, silent anamnesis, platelet count and PT and PTT in normal range and the onset of haemorrhagic problems: all these aspects contribute to deviating one's attention. The result was devastating: four re-exploration surgeries and two free flap failures. The 4T test could be a valid aid for HITT diagnosis because clinical evaluation alone is insufficient and laboratory confirmation requires cost and time. At present, the most useful and feasible tool for HITT suspicion is complete anamnesis investigating not only coagulopathic risk, as proposed by Friedman et al. ${ }^{22}$, but also investigating prior heparin exposure (Table III).
Table III. Pre-operative assessment.

\section{Pre-op questionnaire}

1. Have you or anyone in your family have had a blood clot?

2. Have you or anyone in your family ever been on blood thinners?

3. Have you or anyone in your family ever been diagnosed with a blood clotting disorder?

4. Has anyone in your family had a disease called "purpura fulminans"?

5. Have you ever been diagnosed with Lupus or anyother autoimmune disease?

6. For female patients: Have you ever had a miscarriage?

7. Have you ever been exposed to heparin?

\section{References}

1 Wong CH, Wei FC. Microsurgical free flap in head and neck reconstruction. Head Neck 2010;32:1236-45.

2 Salvatori P, Paradisi S, Calabrese L, et al. Patients survival after free flap reconstructive surgery of head and neck squamous cell carcinoma: a retrospective multicentre study. Acta Otorhinolaryngol Ital 2014;34:99-104.

3 Almadori G, Rigante M, Bussu F, et al. Impact of microvascular free flap reconsctruction in oral cavity cancer: our experience in 130 cases. Acta Otorhinolaryngol Ital 2015;35:386-93.

4 Baj A, Bolzoni A, Torretta S, et al. Arterial microanastomoses on the reverse flow of the internal carotid artery reverse flow: an extreme solution in free flap revascularisation. How we do it. Acta Otorhinolaryngol Ital 2014;34:368-71.

5 Hanasono MM, Butler CE. Prevention and treatment of thrombosis in microvascular surgery. J Reconstr Microsurg 2008;24:305-14.

6 Tremblay DM, Harris PG, Gagnon AR, et al. Heparin-induced thrombocytopenia syndrome as a cause of flap failure: a report of two cases. J Plast Reconstr Aesthet Surg 2008;61:78-83.

7 Schleich AR, Oswald TM, Lineaweaver WC. Complete salvage of impending free flap failure in heparin induced thrombocytopenia by emergent institution of therapy with argatroban. J Plastic Reconstr Aestht Surg JPRAS 2008;61:1263-4.

8 Busch KH, Knobloch K, Vogt PM. Evidence for a locally limited form of heparin-induced thrombocytopenia in plastic reconstructive surgery? Plast Reconstr Surg 2009;124:277-8e.

9 McCleave MJ. Free flap failure caused by heparin-induced thrombocytopenia. Microsurgery 2010;30:251-2. 
10 Medina ND, Mehan V, Schmidt ST. Heparin-induced thrombocytopenia leading to flap failure: Hirudo medicinalis and implications. Plast Reconstr Surg 2010;125:217-9e.

11 Tessler O, Vorstenbosch J, Jones D, et al. Heparin-induced thrombocytopenia and thrombosis as an under-diagnosed cause of flap failure in heparin-naïve patients: a case report and systematic review of the literature. Microsurgery 2014;34:157-63.

12 Zaman SR, Rawlins JM. Heparin induced thrombocytopaenia as a cause of free flap failure in lower limb trauma. J Plast Reconstr Aesthet Surg 2014;67:884-6.

13 SISET. Diagnosi e Terapia della Trombocitopenia Eparinaindotta. 2010 (www.siset.org/linee-guida/linee-guida-siset) (accessed 24/02/2016).

14 Greinacher A. Antigen generation in heparin-associated thrombocytopenia: the non immunologic type and the immunologic type are closelly linked in their pathogenesis. Semin Thromb Hemost 1995;21:106-16.

15 Visentin GP, Ford Se, Scott JP, et al. Antibodies from patient with heparin-induced thrombocytopenia/thrombosis are specific for platelet factor 4 complexed with heparin or bound to endothelial cells. J Clin Invest 1994;93:81-8.

16 Newman PM, Chong BH. Heparin-induced thrombocytopenia: new evidence for the dynamic binding of purified antiPF4-heparin antibodies to platelets and the resultant platelet activation. Blood 2000;96:182-7.
17 Warkentin TE, Kelton JG. Temporal aspects of heparin-induced thrombocytopenia. N Engl J Med 2001;344:1286-92.

18 Bui DT, Cordeiro PG, Hu QY, et al. Free flap reexploration: indications, treatment and outcomes in 1193 free flaps. Plast Reconstr Surg 2007;119:2092-100.

19 Lee KT, Mun GH. The efficacy of postoperative antithrombotics in free flap surgery: a systematic review and metaanalysis. Plast Reconstr Surg 2015;135:1124-39.

20 Serletti JM. Microvascular free flap failure caused by unrecognized hypercoagulability. Plast Reconstr Surg 2009;124:496-9.

21 Davison SP, Kessler CM, Al-Attar A. Microvascular free flap failure caused by unrecognized hypercoagulability. Plast Reconstr Surg 2009;124:490-5.

22 Friedman T, O'Brien Coon D, Michaels VJ, et al. Hereditary coagulopathies: practical diagnosis and management for the plastic surgeon. Plast Reconstr Surg 2010;125:1544-52.

23 Warkentin TE, Heddle NM. Laboratory diagnosis of immune heparin-induced thrombocytopenia. Curr Hematol Rep 2003;2:148-57.

24 Cuker A, Gimotty P, Crowther M, et al. Predictive value of the 4Ts scoring system for heparin-induced thrombocytopenia: a systematic review and meta-analysis. Blood 2012;120:4159e67.

Address for correspondence: Eleonora Segna, Chirurgia Maxillofacciale e Odontostomatologia, Fondazione IRCCS Cà Granda Ospedale Maggiore Policlinico, via Francesco Sforza 35, 20122 Milano, Italy. Tel. +39 02 55032745. Fax +39 02 55032558. Email: elesegna@hotmail.it 